\title{
L011 感謝に関する社会心理学的研究一生起から効果に至るまでー
}

\author{
講演者: 蔵永瞳 (広島大学) \\ 司会者：樋口 匡貴 (広島大学)
}

私たちは，他者から助けられたときなど，日常生活における様々な場面で “感謝”という感情を経験す る。本講演では, この “感謝”という感情に関して, 講演者が実施してきた 3 つの研究を報告する。ま ず研究 1 では, 感謝はどのような状況で生じるのか, どのような内容の感情であるのかという, 感謝に 関する最も基礎的な知見に関する研究を報告する。つぎに研究 2 では, 感謝の生起要因に関する研究を 報告する。生起要因としては, 感謝が生じるような状況におかれたとき, その状況をどのように主観的

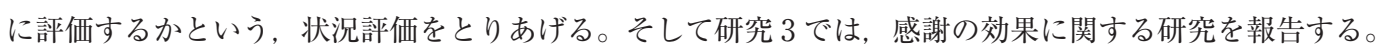
具体的には，感謝後における対人行動（お返しをする，ありがとうと言うなど）や主観的幸福感の促進 メカニズムを検討した研究を報告する。さいごに，3つの研究の知見を統合し, 感謝が生じて効果に至 るまでの過程について論じる。 